\title{
Strategies For Manufacturing Servitization Of Korean SMEs: By Using Data Envelopment Analysis
}

Seung Yin Ha, Sogang University, South Korea

Gun Hee Lee, Sogang University, South Korea

Bum Seok Kim, Sogang University, South Korea

\begin{abstract}
This study examines the efficiency of Korean manufacturing SMEs through data envelopment analysis. We divide business processes into support activities (e.g., business management and product planning) and primary activities (e.g., production and sales and after-sales services) to measure the efficiency of each process by product module. Moreover, we verify the effect of manufacturing servitization by comparing between the efficiency of servitized and non-servitized firms.

The result shows that support activities are generally more efficient than primary activities and that standardized mass production with option (module 2) and totally customized production (module 4) is more efficient than either standardized mass production without option (module 1) or customized assembly after standardized production (module 3). The results suggest that, as SMEs are small, they have an advantage in support activities but also lack production and sales channel infrastructure. Moreover, modules 2 and 4 are relatively efficient because they can increase their product values via product differentiation. In addition, servitized firms are more efficient than nonservitized firms in almost every process and module, implying that servitization in manufacturing is an effective way to improve product value. Finally, module 1 and the production process are relatively inefficient, while servitized firms have higher efficiency scores than do non servitized firms. Likewise, module 3 and sales and after-sales services are relatively inefficient, while servitized firms have higher efficiency scores than do non servitized firms. There results imply that servitization can be used by Korean manufacturing SMEs to develop efficiently and effectively.
\end{abstract}

Keywords: Manufacturing; Servitization; Value Chain; Data Envelopment Analysis; DEA; Efficiency

\section{INTRODUCTION}

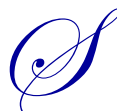
ince the 1970s, Korea has achieved remarkable economic development in manufacturing, such as in textiles, shipbuilding, steel, and auto production. Technological innovation in products was the driving force behind this economic growth. However, differences between products have decreased because of manufacturing standardization and modularization, leading to fiercer price competition. Moreover, technological gaps are narrowing, and new product development cycles are shortening, intensifying competition in the manufacturing industry. For these reasons, manufacturing companies require innovation to compete.

Manufacturing companies are trying to beat the competition by increasing product value in a way that focuses on research and development, license acquisition, marketing, and after-service with the aim of securing a higher margin and stabile revenue. They have been integrating products and services by adding services to products since the late 1990s. For example, Xerox changed its business strategy from being a mere producer and distributor of photocopiers and printers to being a total service company that provides differentiated services such as human resource, customer, and total document management. IBM, a major personal computer manufacturer, sold their PC department to Lenovo in 2004 and implemented strategies focusing on combining products and services into knowledge management, labor force, equipment, and other items. In other words, they increased their service revenue by integrating product and service offerings. Similarly, many manufacturing firms are expanding their business into 
various service ranges and products offered with maintenance and financing, such as vehicle manufacturing and auto lease services, furniture manufacturing and interior design services, and chemical manufacturing and management services. Strategic differentiation can be achieved in manufacturing by integrating product and service offerings and combining products and follow-up services.

However, integrating products and service is not always effective. Reinartz and Ulaga (2008) find that some companies achieve more than half of their total sales through service activities but that other companies fail to obtain a return on service activities despite investing in service development. In Korea, which is heavily dependent on a few large enterprises, large firms become more competitive through product-centric servitized offerings. Many small and medium-sized enterprises (SMEs) find it difficult to offer integrated solutions because of the great cost and effort required and their high sensitivity to economic changes. Thus, servitization can be an innovative strategy for manufacturing, but its effectiveness is not guaranteed. Moreover, SMEs lack the capital needed for servitization, forcing them to concentrate on servitizing specific processes, enhancing efficiency and thus fostering selfsufficiency and long-term growth.

Fang et al. (2008) analyze how servitization affects firm value. Many studies show that large manufacturing companies' provision of additional services with their products improves their business performance. However, few studies have investigated manufacturing SMEs' provision of additional services with products. Therefore, this study suggests a strategy by which Korean SMEs can provide efficient servitization and proposes where to focus their efforts. We employ the value chain model developed by Porter (1985) concerning the manufacturing production process and apply it to SMEs. Considering manufacturing SMEs' value chain, we analyze the efficiency of each process and suggest how SMEs can control their business more effectively. Moreover, we compare among manufacturing companies' performances and empirically measure their service effectiveness.

We use DEA (data envelopment analysis) to measure the efficiency of companies and the servitization of manufacturing SMEs. As SMEs are small, they are not obliged to publicly announce their financial statements, making it difficult to measure SMEs' business performance. Therefore, we used the survey method to obtain the multiple input and output factors of each business process and measure their relative efficiency. This study determines which processes manufacturing SMEs should focus on to improve corporate performance through product-centric servitized offerings, despite SMEs' lack of infrastructure.

\section{LITERATURE REVIEW}

\subsection{Servitization}

The concept of "service" is very widely defined, and its scope in manufacturing is broad, leading the meaning of "service" within manufacturing to become increasingly vague (Johnston, 1999). Levitt (1972) stated that service is included in all industries and that each industry makes different high- and low-service distinctions. Berry and Parasuraman (1991) suggested that there are no differences between products and services because products are combined with services. Thus, it is hard to accurately distinguish between manufacturing and services in all industries. In manufacturing, service was once seen as nothing more than after-sales service; now, it is as important as products. Service creates value-added to complement a tangible product (Wilkinson et al., 2009). Therefore, service cannot be separated from products, and servitization is a fusion of service and product.

According to Neely (2007), "servitization" was first defined by Vandermerwe and Rada (1998). He defined it is a one-time offering of a product, service, resource, knowledge, or self-service. He also explained that servitization occurs in three stages. First, a company provides products or services. Second, the company provides products and services together. Finally, the company not only provides a combination of product and service but also supplies the customer, solves problems, and provides customer self-service. Robinson et al. (2002) stated that servitization is an evolution in which a service is provided after products are sold and in which a service is combined with a product so it cannot be separated from it. Later, Ren and Gregory (2007) defined "servitization" as a strategic change designed to obtain higher corporate performance and competitive advantage (Baines, 2008). Baines (2008) also suggested that servitization is innovation intended to change how a company sells products by integrating products and services and thus enhance value. 
Thus, servitization refers to developing a process and providing a solution to customers via a combination of products and services. Methods of providing services in response to customer characteristics have changed from the days when only products were provided. However, servitization in manufacturing has not always benefited companies. Mathieu (2001) stated that servitization risks exist in terms of expenses and strategy. Expanding services requires costs and new employees; it can also lead to strategic disadvantages because of competition with previous service providers or distributors. Gebauer et al. (2005) described the "service paradox," in which manufacturing companies cannot meet their expectations despite large investments in a service business because of the costs and strategic limitations. Fang et al. (2008) found that firms that didn't reach a certain level of service revenue often suffered reduced productivity and business performance.

Thus, manufacturing companies need to maintain the infrastructure for providing services and recruit new experts for servitization. However, SMEs lack the energy needed for new investments and thus require a method for obtaining the optimum effect through minimum investments in money and recruits.

\subsection{Value Chain}

This study analyzes the value chain to measure SMEs' efficiency through servitization. We employ the value chain developed by Porter (1985) to analyze each process in terms of the margin (i.e., value) produced. Porter (1985) suggested that, although companies develop strategies based on their organization and the external business environment, their strategies can fail if they are not applied to each process. He saw the value chain as the link between establishing and applying a strategy and analyzed each process in terms of its value added to products or services. Through the value chain, the organization can organize the steps in each process and develop an efficient strategy for each one.

The value chain divides firm activities into primary and support activities. Primary activities are further divided into inbound logistics, operations, outbound logistics, marketing and sales, and after-sale service. Support activities are divided into firm infrastructure, human resource management, technology development, and procurement. Companies must analyze the key value-added activities of each process and establish a strategy by which to gain a competitive advantage.

A company enjoys competitiveness when its products are different from those of competitors; it can then provide a wide range of products with more value or increase productivity with lower manufacturing cost. Product and price differentiation between companies are determined during the planning, producing, and selling of products and services. The company can increase revenue through these differences. In other words, competitive power is created through all business activities, and companies should combine resources to create more valuable products and services.

However, it is difficult to apply the existing value chain structure to SMEs. Therefore, we redefine and simplify the model dividing support activities and primary activities to suit SMEs, and consider available resources, level of technology, and core capabilities instead. This classification provides a basic framework for a comparison of each process in strategic terms. The value chain model for analyzing the strength of SME servitization is presented in Figure 1 below. 
Figure 1. Manufacturing SMEs' Value Chain

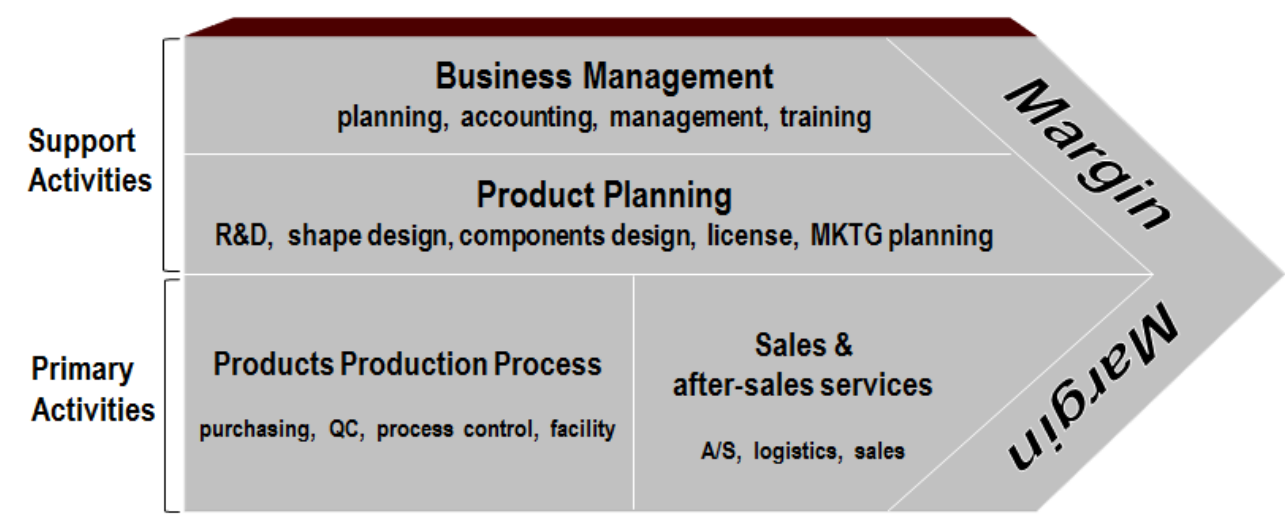

We divide primary activities into production and sales and after-sales services and further divide support activities into business management and product planning. The production process runs from raw material to complete material and comprises the purchasing of raw material, QC (quality control of the products), process control (including production process design and improvement), and facility (such as maintenance). The sales and aftersales services process is divided into three steps: logistics (such as product delivery and shipping), sales, and afterservice. Additionally, business management as a support activity involves planning, accounting, management, and employment training. Finally, product planning comprises R\&D, product shape design, component design, licensing, and marketing planning. This study determines the most efficient method of increasing production using fewer inputs for small businesses with relatively scant resources through a DEA analysis of each process of this value chain.

\subsection{A Brief Introduction to Data Envelopment Analysis}

In general, efficiency is defined and calculated as the sum of weighted outputs over the sum of weighted inputs. A relatively efficient firm achieves more output levels with the given input levels or achieves similar output levels with smaller input levels than other firms. However, it is hard to estimate efficiency because it is difficult to decide the weights of various inputs and outputs, and the scale of each input and output is different. Moreover, there is no standard point at which they can be deemed efficient, making evaluation difficult even after efficiency has been calculated. These limitations can be overcome by using DEA to measure relative efficiency.

The DEA method was first proposed by Charnes et al. (1978). It measures efficiency as the sum of the weighted outputs and inputs but does not assign a weight without a scale modification of the inputs and outputs. The DEA provides an efficiency score on a range from 0 to 1 , where 1 indicates efficient and other values indicate degrees of inefficiency. Moreover, the DEA is a non-parametric method that does not need statistical assumptions. Because of these characteristics, the DEA has been widely used in various fields and industries to measure the efficiency of elearning systems and productivity changes and to suggest appropriate CEO remuneration (Isik \& Hassan, 2003; Manna, 2012; Theunissen \& Oberholzer, 2013). Eq (1) is the mathematical formulation of the CCR model used in the basic DEA: 


$$
\begin{array}{ll}
\operatorname{Max} & E_{k}=\sum_{r=1}^{s} u_{r} y_{r k} \\
\text { s.t. } & \sum_{i=1}^{m} v_{i} x_{i k}=1 \\
& \sum_{r=1}^{s} u_{r} y_{r j}-\sum_{i=1}^{m} v_{i} x_{i j} \leq 0, \quad j=1, \cdots, k, \cdots, n \\
& u_{r} \geq \varepsilon \geq 0, r=1, \cdots, s \\
& v_{i} \geq \varepsilon \geq 0, i=1, \cdots, m
\end{array}
$$

In Eq (1), $x_{i}$ indicates $i$ th input and $v_{i}$ indicates the corresponding weight of input $i$; $y_{r}$ indicates $r$ th output and $u_{r}$ indicates the corresponding weight of output $r ; j$ indicates decision-making unit (DMU), and $k$ indicates target DMU, measured as relative efficiency; $\varepsilon$ indicates a very small positive number. The DEA assigns optimal weights to inputs and outputs under the constraint that the maximum efficiency score is 1 by using the Linear Programming model. The objective function is that the maximum weighted sum of outputs subject to the weighted sum of inputs is 1, under the first constraint. This is a linear form of the efficiency formula defined as the weighted sum of outputs over the weighted sum of inputs with the denominator restricted to 1 . This objective function is the efficiency score. The DEA restricts the maximum efficiency score to 1 under the second constraint. As the DEA assigns the optimal weights to maximize the efficiency formula and the maximum efficiency score is 1 , the efficiency score must be 1 when the DMU is efficient. Efficiency scores below 1 are strong evidence of inefficiency because a DMU is not assigned the highest value even if it is assigned the optimal weight.

\section{EMPIRICAL TEST}

\subsection{Test Design}

The main purpose of this study is to examine manufacturing SMEs and verify the effect of manufacturing servitization. To this end, we first check the relative efficiency in the manufacturing industry. We divide core manufacturing processes into four levels and corresponding activities according to the SMEs' value chain and business environment. Each level has its own inputs and outputs. We can calculate the relative efficiency of each level using these inputs and outputs, thus determining the efficiency of each process level and identifying which ones are operating efficiently. We use a DEA model to measure relative efficiency. As our focus is SMEs, we assume a constant return to scale fit for the DEA-CCR model. We use the DEA efficiency score as a measure of efficiency and compare among average efficiency scores.

Because we are interested in not absolute but relative efficiency, the firms evaluated by the DEA model need to have similar attributes. Therefore, we classify our dataset into four modules: standardized mass production without option, standardized mass production with option, customized assembly after standardized production, and totally customized production. After segmenting the modules, we compare among their average efficiency scores to determine which ones are operating efficiently. Thus, we compare the relative efficiency among not only the manufacturing processes but also the modules. To compare the average efficient scores of the processes and modules, we may consider ANOVA, used to compare average values among more than three groups. However, the DEA is a non-parametric method of measuring relative efficiency, and a non-parametric statistical method is preferable to a parametric test such as ANOVA. Thus, we employ the Kruskal-Wallis test to compare efficiency among the processes and modules and a Wilcoxon rank sum test with Bonferroni correction for analyses of the Kruskal-Wallis test.

After determining which processes and modules are efficient, we verify the effect of manufacturing servitization by calculating the average efficiency scores of servitized firms and comparing them with the average efficiency scores of non-servitized firms for each process level and module. This analysis allows us to determine which process and module are impacted by servitized manufacturing and thus build an effective servitization strategy. The compared 
efficient scores are calculated by the DEA, a non-parametric method, and the Mann-Whitney test, a non-parametric statistical method, is used to compare the two independent groups.

\subsection{Survey and Inputs/Outputs}

Firms' financial statements are typically used to measure input and output factors. For SMEs, however, it is impossible to collect financial statements. Thus, we use the survey method. Our survey involves manufacturing companies selected through KSCI (Korean Standard Industrial Classification) of KOSTAT (Statistics Korea). We divided manufacturing into four levels and corresponding activities within manufacturing SMEs' value chain. The first level is business management, with the corresponding activities of business planning, accounting, management, and employee training. The second level is product planning, which includes $\mathrm{R} \& \mathrm{D}$, shape design, component design, licensing, and marketing planning. Third is production, which includes purchasing, quality control, process control, and facility. The last level is sales and after-sales services, which involves after-sales service, logistics, and sales. The survey investigates the changes in costs and employees required by each activity; the results are used as input variables for the DEA model.

Then, we investigate business performance in terms of strategy, costs, flexibility, and quality. For strategy, we survey how much performance is improved in terms of creating innovative products, creating a growth engine, and pioneering new markets, which are the outcomes of firms' business management. For costs, we survey how much performance is improved in terms of decreased non-operation costs (the outcome of business management), decreased operation cost (the outcome of production), and price competitiveness (the outcome of sales and aftersales services). For flexibility, we survey how much performance is improved in terms of product customizing and diversification (the outcomes of product planning) and responsiveness to customers (the outcome of sales and aftersales services). For quality, we survey how much performance is improved in terms of product design, product function, the performance outcomes of product planning, product quality, and product defective rates. For time, finally, we survey how much performance is improved in terms of product development duration (the outcome of product planning), operating time (the outcome of product production), and delivery time (the outcome of sales and after-sales services). These survey results are used as the outputs of the corresponding process levels in the DEA model.

We also investigate firm sales over three years and calculate sales growth to measure firms' overall performance. We use the sales growth rate as an output for each business process level. The input and output variables used in the DEA model to measure relative efficiency are shown in Table 1.

Table 1. Input/Output Variables for DEA

\begin{tabular}{|c|c|c|c|c|}
\hline Process & \multicolumn{2}{|c|}{ Inputs } & \multicolumn{2}{|r|}{ Outputs } \\
\hline \multirow{4}{*}{$\begin{array}{l}\text { Business } \\
\text { Management }\end{array}$} & Planning & Employee, Cost & Overall & Sales Growth Rate (\%) \\
\hline & Accounting & Employee, Cost & \multirow{2}{*}{ Strategy } & Innovative Product, Growth Engine, Pioneer \\
\hline & Management & Employee, Cost & & New Market \\
\hline & Training & Employee, Cost & Cost & Decreasing Non-operation Cost \\
\hline \multirow{5}{*}{$\begin{array}{l}\text { Product } \\
\text { Planning }\end{array}$} & $\mathrm{R} \& \mathrm{D}$ & Employee, Cost & Overall & Sales Growth Rate (\%) \\
\hline & Shape Design & Employee, Cost & Flexibility & Customized Product, Product Diversification \\
\hline & Component Design & Employee, Cost & \multirow{2}{*}{ Quality } & Design of the Product, \\
\hline & License & Employee, Cost & & Product Function and Performance \\
\hline & MKTG Planning & Employee, Cost & Time & Improve Developing Time \\
\hline \multirow{4}{*}{$\begin{array}{l}\text { Product } \\
\text { Production } \\
\text { Process }\end{array}$} & Purchasing & Employee, Cost & Overall & Sales Growth Rate (\%) \\
\hline & $\mathrm{QC}$ & Employee, Cost & Cost & Decreasing Operation Cost \\
\hline & Process Control & Employee, Cost & Quality & Product Quality, Defective Rate \\
\hline & Facility & Employee, Cost & Time & Improve Operating Time \\
\hline \multirow{4}{*}{$\begin{array}{l}\text { Sales \& after- } \\
\text { sales services }\end{array}$} & \multirow{2}{*}{ after-sales services } & \multirow{2}{*}{ Employee, Cost } & Overall & Sales Growth Rate (\%) \\
\hline & & & Cost & Price Competitiveness \\
\hline & Logistics & Employee, Cost & Flexibility & Customer Response \\
\hline & Sales & Employee, Cost & Time & Decreasing Delivery Time \\
\hline
\end{tabular}




\subsection{Sample Selection}

Through the survey, we collect data from 4,717 Korean manufacturing firms. Among them, companies in module 1 account for $12.6 \%$, those in module 2 account for $244.8 \%$, those in module 3 account for $10.4 \%$, and those in module 4 account for $32.3 \%$. Only SME and B2B firms are selected. Thus, we exclude firms with fewer than 10 or more than 1,000 employees, following the criteria on Korean SMEs of the SMBA (Small and Medium Business Administration). The number of excluded firms is 1,355 (3,362 are B2B firms). We also exclude 2,169 firms with missing answers to maintain test robustness. Thus, our final sample comprises 1,193 firms. The sample described by module and servitized status is presented in Table 2. As can be seen, module 2, standardized mass production with option, is the largest (647), and module 3, customized assembly after standardized production, is the smallest (126). Module 1 has the most servitized firms and module 2 the least.

Table 2. The Number of Firms Classed by Module

\begin{tabular}{|c|c|c|c|c|}
\hline \multirow{2}{*}{\multicolumn{2}{|c|}{ Module }} & \multicolumn{3}{|c|}{ Number of firms } \\
\hline & & \multirow{2}{*}{$\begin{array}{c}\text { Servitized firms } \\
101\end{array}$} & \multirow{2}{*}{$\begin{array}{c}\begin{array}{c}\text { Non-servitized } \\
\text { firms }\end{array} \\
59\end{array}$} & \multirow{2}{*}{$\begin{array}{c}\begin{array}{c}\text { Total number } \\
\text { (Proportion) }\end{array} \\
160(13.41 \%)\end{array}$} \\
\hline 1 & Standardized Mass Production without option & & & \\
\hline 2 & Standardized Mass Production with option & 42 & 605 & $647(54.23 \%)$ \\
\hline 3 & Customized Assembly after Standardized Production & 48 & 78 & $126(10.56 \%)$ \\
\hline 4 & Customized Production & 94 & 166 & $260(21.79 \%)$ \\
\hline & Total & 285 & 908 & $1,193(100 \%)$ \\
\hline
\end{tabular}

\section{RESULTS}

\subsection{Test Results}

We examine each of the four processes in each of the four modules via DEA tests; a total of 16 average efficiency scores are calculated. Table 3 shows the number of efficiency scores of 1, and Table 4 shows the average efficiency scores of each analysis.

Table 3. The Number of Efficient Firms in DEA

\begin{tabular}{l|c|c|cc}
\hline & $\begin{array}{c}\text { Business } \\
\text { Management }\end{array}$ & $\begin{array}{c}\text { Product } \\
\text { Planning }\end{array}$ & $\begin{array}{c}\text { Product } \\
\text { Production }\end{array}$ & $\begin{array}{c}\text { Sales \& after-sales } \\
\text { services }\end{array}$ \\
\hline Module 1 & $32(20.00 \%)$ & $08(5.00 \%)$ & $06(3.75 \%)$ & $24(15.00 \%)$ \\
\hline Module 2 & $32(4.95 \%)$ & $80(12.36 \%)$ & $30(4.64 \%)$ & $\mathbf{2 4}(\mathbf{3 . 7 1 \% )}$ \\
\hline Module 3 & $\mathbf{3 1 ( 2 4 . 6 0 \% )}$ & $10(7.94 \%)$ & $17(13.49 \%)$ & $08(6.35 \%)$ \\
\hline Module 4 & $18(6.92 \%)$ & $33(12.69 \%)$ & $29(11.15 \%)$ & $18(6.92 \%)$ \\
\hline
\end{tabular}

Table 4. Average Efficiency Scores in DEA

\begin{tabular}{l|c|c|c|c|c}
\hline & $\begin{array}{c}\text { Business } \\
\text { Management }\end{array}$ & $\begin{array}{c}\text { Product } \\
\text { Planning }\end{array}$ & $\begin{array}{c}\text { Product } \\
\text { Production }\end{array}$ & $\begin{array}{c}\text { Sales \& after- } \\
\text { sales services }\end{array}$ & Total \\
\hline Module 1 & 0.8101 & $\mathbf{0 . 4 7 5 8}$ & 0.5216 & 0.7510 & 0.6396 \\
\hline Module 2 & 0.7484 & $\mathbf{0 . 8 3 8 3}$ & 0.7160 & 0.6937 & 0.7491 \\
\hline Module 3 & 0.8117 & 0.5476 & 0.6596 & 0.4795 & 0.6246 \\
\hline Module 4 & 0.6475 & 0.7638 & 0.7418 & 0.7063 & 0.7149 \\
\hline Total & 0.7414 & 0.7428 & 0.6896 & 0.6815 & \\
\hline
\end{tabular}

As Table 3 shows, module 3 has the most firms efficient in business management, and module 2 has the least firms efficient in sales and after-sales services. Table 4 shows that the processes' order of efficiency is product planning $(0.7428)$, business management $(0.7414)$, product production $(0.6896)$, and sales and after-sales services $(0.6815)$; by module, the order is module 2 (mass production with option; 0.7491 ), module 4 (totally customized production; 0.7149), module 1 (mass production without option; 0.6396), and module 3 (customized assembly with mass production; 0.6246). Product planning in module 2 is the most efficient process, and product planning in module 1 is the least efficient. Let us examine the efficiency of each process and module in more detail. 


\subsubsection{Comparing Efficiency among Processes}

The result of the Kruskal-Wallis test and a post analysis with Bonferroni's correction reveal significant differences in efficiency among processes, as shown in Table 5.

Table 5. Result of Comparing Efficiency among Processes

\begin{tabular}{|c|c|c|c|c|}
\hline & $\begin{array}{l}\text { Business Mgt. } \\
\text { (Process 1) }\end{array}$ & $\begin{array}{l}\text { Product Planning } \\
\text { (Process 2) }\end{array}$ & $\begin{array}{c}\text { Product Production } \\
\text { (Process 3) }\end{array}$ & $\begin{array}{l}\text { Sales \& after-sales } \\
\text { services (Process 4) }\end{array}$ \\
\hline Average Efficiency Score & 0.7414 & 0.7428 & 0.6896 & 0.6815 \\
\hline Mean Rank Sum Score & 2630.3797 & 2726.4489 & 2167.0444 & 2022.1270 \\
\hline \multirow{2}{*}{ Kruskal-Wallis Test } & Chi-Square & P-Value & \multicolumn{2}{|c|}{ Post Analysis (Bonferroni's Method) } \\
\hline & 223.9199 & $<.0001$ & \multicolumn{2}{|c|}{$\mathrm{P} 2>\mathrm{P} 1>\mathrm{P} 3>\mathrm{P} 4$} \\
\hline
\end{tabular}

The result shows significant differences in efficiency; the process levels all have statistically different efficiencies. Moreover, product planning is the most efficient, followed by business management and product production; sales and after-sales services is the most inefficient. Thus, SMEs are relatively efficient at support activities and inefficient at primary activities.

These results suggest that SMEs conduct product planning to compete with large enterprises. A number of Korean SMEs are subcontractors of large enterprises and thus do their best to maintain relationships with contractors by designing good products. In terms of business management, SMEs lack assets such as employees, capital, and other resources, but it can be also provided a management advantage because they can be organizing the firm efficiently and it can make the optimized business planning. However, production and sales and after-sales services are different: SMEs lack the equipment needed for production and sales channels; retaining these is thus practically impossible for them.

\subsubsection{Comparing Efficiency among Processes}

The result of the Kruskal-Wallis test and post analysis with Bonferroni's correction show significant differences in efficiency among modules, as shown in Table 6.

Table 6. Result of Comparing Efficiency among Modules

\begin{tabular}{l|c|c|c|c}
\hline & Module 1 & Module 2 & Module 3 & Module 4 \\
\hline Average Efficient Score & 0.6396 & 0.7491 & 0.6246 & 0.7149 \\
\hline Mean Rank Sum Score & 1882.5273 & 2676.5616 & 1729.2708 & 2293.3332 \\
\hline \multirow{2}{*}{ Kruskal-Wallis Test } & Chi-Square & P-Value & Post Analysis (Bonferroni's Method) \\
\cline { 2 - 5 } & 320.0700 & $<.0001$ & M2 $>$ M4 $>$ M1 $=$ M3 \\
\hline
\end{tabular}

The result shows a significant difference in efficiency among modules. Module 2 is the most efficient, followed by module 4; modules 1 and 3 are equally inefficient. Thus, firms with mass production with option or totally customized production operate efficiently, and those with mass production without option and customized assembly operate inefficiently.

What we know about economies of scale led us to assume that module 1 would operate most efficiently and module 4 most inefficiently, but the results differ from our expectation, likely because our sample consists of SMEs.

\subsubsection{Effect of Servitization}

The result of the Mann-Whitney test to verify the significant differences in efficiency between servitized and nonservitized firms is shown in Table 7. 
Table 7. Result of Comparing Efficiency between Servitized and Non-servitized Firms

\begin{tabular}{l|c|c|c|c|c|c|c|c}
\hline \multirow{2}{*}{} & \multicolumn{2}{|c|}{ Business Mgmt. } & \multicolumn{2}{|c|}{ Product Planning } & \multicolumn{2}{|c|}{ Product Production } & \multicolumn{2}{c}{$\begin{array}{c}\text { Sales \& after-sales } \\
\text { services }\end{array}$} \\
\cline { 2 - 9 } & Servitized & Non & Servitized & Non & Servitized & Non & Servitized & Non \\
\hline Module 1 & $0.8251^{* *}$ & 0.7845 & $0.4882^{*}$ & 0.4546 & $0.5436^{* * *}$ & 0.4840 & 0.7340 & 0.7697 \\
\hline Module 2 & $0.7821^{*}$ & 0.7461 & $0.8664^{* *}$ & 0.8364 & $0.7832^{* * *}$ & 0.7114 & 0.7093 & 0.6926 \\
\hline Module 3 & 0.8062 & 0.8151 & $0.5783^{*}$ & 0.5287 & 0.6566 & 0.6614 & $0.5021^{*}$ & 0.4656 \\
\hline Module 4 & $0.6809^{* *}$ & 0.6285 & $0.7802^{*}$ & 0.7546 & $0.7624^{* *}$ & 0.7302 & $0.7197^{*}$ & 0.6988 \\
\hline
\end{tabular}

Note: The figures in the table show the Mann-Whitney test results, which are used to compare efficiency scores between servitized and nonservitized firms; $*$ denotes significance at the $10 \%$ level; $* *$ denotes significance at $5 \%$, and $* * *$ denotes significance at $1 \%$.

As can be seen from the table above, most servitized firms are more efficient than non-servitized firms. For process 2 (product planning), the most efficient process, servitized firms have significantly high efficiency in the module. Process 1 (Business Management) is also significantly efficient for servitized firms, except in module 3. Thus, servitized firms are more efficient than non-servitized firms in support activities. Process 3 (product production) is significantly efficient in servitized firms, except for module 3; for process 4 (sales and after-sales services), however, only modules 3 and 4 are significantly efficient. Thus, we can confirm that the servitization of SMEs is more inefficient in primary activities, especially in sales and after-sales services, than in support activities. These results indicate where to concentrate in order to enhance operational efficiency.

\subsection{Discussion}

Our results indicate that Korean SMEs are efficient in support activities (i.e., processes 1 and 2) and that the most efficient process is process 2. Korean SMEs produce relatively few products and can organize their schedules easily, making them more effective. Process 1 is highly efficient because SMEs perform multiple tasks with little manpower. They don't need a large workforce to manage tasks such as planning, accounting, and training, and they can make management decisions quickly. The primary activities in processes 3 and 4 are less efficient than the support activities because they require a large workforce and more equipment expenses for production. Consequently, SMEs' activities in the value chain are more efficient in support activities than in primary activities. Concerning the modules, 2 and 4 are the most efficient. Module 2 involves the product type, which has a standardized mass production system with standardized options. This type features product differentiation in a way that adds options to mass-produced products. Module 4 involves customized products and has a competitive edge over other manufacturing companies through differentiated products that reflect customer needs. We can confirm that SMEs that produce specialized products are more efficient. By contrast, modules 1 and 3 are less efficient. Module 1 involves standardized mass produced products, and module 3 involves standardized semi-finished products assembled according to customer requirements. Module 1 (mass produced products) has no alternative but to compete in price. In this structure, as intensifying price competition includes large enterprises, SMEs could lose their margin. In module 3, it is difficult for SMEs to differentiate their semi-finished products; product differentiation is possible, but it tends to increase prices excessively. Consequently, SMEs in modules 1 and 3 are less efficient than are those in modules 2 and 4.

The result of comparing servitized and non-servitized firms is as follow. First, servitized firms are more efficient than non-servitized firms in almost every process and module. For sales and after-sales services, however, there is little difference in efficiency between servitized and non-servitized firms. We will discuss the servitization of process 4 for each module. Module 1 features many competitors because it produces mass-produced products without product differentiation. In this structure, product prices will be lower, and margins will also decrease; thus, a servitization of sales and after-sales services may not improve performance. In module 2 , for process 4 , customers are more various and product options are complicated and diversified, presenting another burden for SMEs in terms of sales, logistics, and after-sales services. In modules 3 and 4 , servitized firms are more efficient than nonservitized firms, as module 3 for semi-finished products and module 4 for customized products have fewer customers than the other modules. Consequently, as seen in Gebauer at al. (2010), SMEs have an advantage in selling directly to few customers, considering their limited resources.

Finally, we can suggest some strategies for Korean SMEs. They have an advantage in support activities and should thus maintain their current focus. Primary activities are relatively inefficient in modules 1 and 3. Servitized firms 
have significantly higher efficiency than non-servitized firms in product production in module 1 and sales and aftersales services in module 3 . Thus, module 1 can improve its efficiency via the servitization of product production, and module 3 can improve its efficiency via the servitization of sales and after-sales services.

\section{CONCLUSION}

The development of technology has created keen competition in the manufacturing industry. Korean SMEs have become highly dependent on large enterprises and must innovate to foster self-sufficiency and long-term growth. We measure the efficiency of Korean SMEs to determine which processes and product modules are efficient. We then verify the effect of servitization, the integration of product and service offerings, to suggest strategies for Korean SMEs. For empirical testing, we employ DEA to measure relative efficiency using 1,193 Korean SMEs. We divide processes into four steps based on Porter's (1985) value chain: business management (process 1), product planning (process 2), product production (process 3 ), and sales and after-sales services (process 4). We segment the product module into four types: standardized mass production without option (module 1), standardized mass production with option (module 2), customized assembly after standardized production (module 3), and totally customized production (module 4). We measure the efficiency of each process and module.

The test results can be summarized as follows. First, support activities such as process 1 and 2 are more effective than are primary activities such as process 3 and 4, indicating that SMEs do not have a wide product range and that manufacturers can optimize planning and scheduling with optimized human resources. Thus, SMEs can improve their efficiency via product differentiation.

Second, the modules' order of efficiency is $2,4,1$, and 3. Intuitively, we expect the order of efficiency to increase monotonously from module 1 to 4 because of economies of scale. However, SMEs (our sample) find it hard to compete with large enterprises. In module 2, they can increase product value via product differentiation with option; in module 4 , they can pursue product competitiveness via customized production.

Finally, the efficiency analysis comparing servitized to non-servitized firms shows that servitized firms are more efficient in support activities but less efficient in some primary activities. Module 3 was not efficient in product production, and modules 1 and 2 were not efficient in sales and after-sales services. As SMEs have difficulties investing and securing distribution channels, they can overcome these inefficiencies by selling customized products to a small group of customers and selling products to customers via original equipment manufacturing (OEM); this will increase operational efficiency. Sales and after-sales services can be made more efficient by selling products and providing after-sales service though another distributer without using another distribution channel. In addition, the inefficient modules 1 and 3 and the inefficient processes 3 and 4 can also be improved. Module 1 and product production are relatively inefficient but are more efficient in servitized firms than in non servitized firms. Likewise, module 3 and sales and after-sales services process are relatively inefficient but are more efficient in servitized firms than in non servitized firms. Thus, servitization can help Korean manufacturing SMEs to develop efficiently and effectively.

Oliva and Kallenberg (2006) argue that the revenue from integrating products and services is subject to fewer fluctuations than revenue from product sales alone, ensuring cash flow. Moreover, services are more difficult to imitate than products are and can thus lead to a sustained competitive advantage. We empirically examine whether this argument is valid for Korean SMEs. The servitization of SMEs produces more stable margins and helps sustain a market advantage via product differentiation.

\section{AUTHOR BIOGRAPHIES}

Seung Yin Ha is a Ph.D. Candidate, Management Science at the Sogang University Business School. His research focuses on modeling and managing credit risks, Credit scoring system in bank industry, corporate social responsibility. E-mail: seyinha@sogang.ac.kr

Dr. Gun Hee Lee is a Professor of Management Science at the Sogang University Business School. He received his Doctorate in department of statistics, University of Missouri at Columbia, USA, in 1996. Professor Lee has carried 
out research projects on the strategy for modeling and operations, financial technology, business analysis and corporate valuation, development of the intelligent, automated and predictive statistical model based on the large databases. E-mail: ghlee@sogang.ac.kr

Bum Seok Kim received his Ph.D. degree at the Business School of Sogang University in February, 2016. His research focuses on measuring firm's efficiency, corporate social responsibility, and decision making.

(Corresponding Author) E-mail: bs4eva0615@gmail.com

\section{REFERENCES}

Baines, T.S., Lightfoot, H.W., Benedettini O., \& Kay, J.M. (2008), The servitization of manufacturing, International Journal of Operation \& Production Management, 20(5), 547-567

Berry, L. L., \& Parasuraman, A. (1991), Marketing Services: Competing Though Quality, New York: Free Press

Charnes, A., Cooper, W.W., \& Rhodes, E. (1978). Measuring the efficiency of decision making units. European Journal of Operational Research, 2(6), 429-444.

Fang, E., Palmatier, R. W., \& Steenkamp, J.-B. E. M. (2008), Effect of Service Transition Strategies on Firm Value, Journal of Marketing, 72(5), 1-14.

Gebauer, H., Fleisch, E., \& Friedli, T. (2005), Overcoming the Service Paradox in Manufacturing Companies, European Management Journal, 23(1), 14-26.

Gebauer, H., Paiola, M., \& Edvardsson, B. (2010), Service business development in small and medium capital goods manufacturing companies, Managing Service Quality, 20(2), 123-139.

Isik, I., \& Hassan, M.K. (2003). Financial deregulation and total factor productivity change: An empirical study of Turkish commercial banks, Journal of Banking \& Finance, 27(8), 1455-1485.

Johnston, R. (1999), Service operations management: return to roots, International Journal of Operations \& Production Management, 19(2), 104-124.

Levitt, T. (1972), Production-line approach to service, Harvard business review, 50(5), 41-52.

Manna, R. (2012). Effective learning through E-learning system: DEA approach, IEEE Proceedings of 4th International Conference on Intelligent Human Computer Interaction.

Mathieu, V. (2001), Service strategies within the manufacturing sector: benefit, costs and partnership, International Journal of Service Industry management, 12(5), 451-475

Neely, A. (2007), The servitization of manufacturing: An analysis of global trends, 14th European Operations Management Association Conference, Ankara, Turkey.

Oliva, R., \& Kallenberg, R. (2006), Managing the transition from products to services, International Journal of Service Industry Management, 14(2), 160-172.

Porter, M. (1985), Competitive Advantage: Creating and Sustaining Superior Performance, New York: Fre e Press

Reinartz, W., \& Ulaga, W. (2008), How to Sell Services More Profitably, Harvard business review, 86(5), 90-96.

Theunissen, M., \& Oberholzer, M. (2013). An application of data envelopment analysis to benchmark CEO remuneration: A South African study, Journal of Applied Business Research, 29(5), 1509-1522.

Wilkinson, A., Dainty, A., \& Neely, A. (2009). Changing times and changing timescales: the servitization of manufacturing, International Journal of Operations \& Production Management, 29(5). 


\section{NOTES}

